\title{
Prospection of the quality and bioactive potential of the seedless watermelon
}

Prospecção da qualidade e potencial bioativo de híbridos de melancia sem sementes

\author{
M. M. T. de Oliveira ${ }^{1 *}$; R. E. Alves ${ }^{2} ;$ L. R. Silva ${ }^{3}$; N. D. Barreto ${ }^{3}$ \\ ${ }^{1}$ Ben-Gurion University of the Negev, The French Associates Institute for Agriculture and Biotechnology of Drylands, \\ 84990, Midreshet Ben-Gurion, Israel. \\ ${ }^{2}$ Brazilian Agricultural Research Corporation, Food and Territories, 57020-520, Maceió, AL, Brazil. \\ ${ }^{3}$ Department of Plant Sciences, UFERSA-RN, 59625-900, Mossoró, RN, Brazil. \\ *phdmilenaoliveira@gmail.com \\ (Recebido em 10 de outubro de 2019; aceito em 02 de maio de 2020)
}

\begin{abstract}
The present investigation aimed to evaluate the prospection of the quality and the bioactive potential of four seedless watermelon hybrids. Fruits were collected from the commercial farms located at the Jaguaribe-Açu agricultural Valley/RN and Jaguaribe Valley/CE, Brazil. Plant material included the hybrids 'Ashira', 'Extasy', 'Mickylee' and 'Valentino'. The following parameters were evaluated: fruit weight; longitudinal and transverse diameter; fruit shape index; pulp firmness; pulp color; shell thickness; soluble solids, titratable acidity, $\mathrm{pH}$, soluble solids and titratable acidity ratio, total and reducers soluble sugars, vitamin $\mathrm{C}$, total carotenoids, lycopene, yellow flavonoids, total anthocyanins and total polyphenols. The trial was carried out by a completely randomized design. The comparison of means was performed using one way ANOVA at the Tukey HSD test. All the hybrids showed fruits small, i.e., "icebox" type, with mean values lower than 5.5 $\mathrm{kg}$, spherical shape and a higher portion of edible pulp. The fruits showed high pulp firmness leading a great resistance to mechanical injuries sustained due to transport, besides long postharvest shelf life. 'Ashira' showed the highest proportion of sugars present in the fruit due to the increase of $73 \%$ in the SS/AT ratio compared to the other hybrids. 'Extasy' presented high content of total carotenoids whereas 'Ashira' stood out in the content of total polyphenols. The hybrids are promising alternatives to the local and export watermelon market, in view of the high quality and bioactive potential linked to the good adaptability and stability under the growth conditions.
\end{abstract}

Keywords: Citrullus lanatus, postharvest, lycopene.

A presente investigação teve como objetivo avaliar a prospecção da qualidade e o potencial bioativo de quatro híbridos de melancia sem sementes. Os frutos foram coletados nas fazendas comerciais localizadas no Vale Agrícola de Jaguaribe-Açu/RN e Vale do Jaguaribe/CE, Brasil. Os híbridos utilizados foram: 'Ashira', 'Extasy', 'Mickylee' e 'Valentino'. Os seguintes parâmetros foram avaliados: massa do fruto; diâmetros longitudinal e transversal; índice de formato do fruto; firmeza da polpa; cor da polpa; espessura da casca; sólidos solúveis, acidez titulável, $\mathrm{pH}$, relação sólidos solúveis e acidez titulável, açúcares solúveis totais e redutores, vitamina $\mathrm{C}$, carotenóides totais, licopeno, flavonóides amarelos, antocianinas totais e polifenóis totais. O experimento foi realizado por um delineamento inteiramente casualizado com a comparação das médias realizada via ANOVA pelo teste Tukey HSD. Todos os híbridos apresentaram frutos pequenos, tipo "icebox", com valores médios inferiores a 5,5 kg, formato esférico e maior porção de polpa comestível. Os frutos apresentaram alta firmeza da polpa o que leva a uma maior resistência à lesões mecânicas sofridas durante o transporte, além de maior vida útil pós-colheita. 'Ashira' apresentou a maior proporção de açúcares presentes no fruto devido ao aumento de $73 \%$ na razão SS/AT em comparação com os outros híbridos. 'Extasy' apresentou alto teor de carotenóides totais, enquanto 'Ashira' se destacou no conteúdo de polifenóis totais. Os híbridos avaliados são alternativas promissores para o mercado de melancia local e de exportação, devido à alta qualidade e potencial bioativo associado à boa adaptabilidade e estabilidade sob as condições de crescimento.

Palavras-chave: Citrullus lanatus, pós-colheita, licopeno.

\section{INTRODUCTION}

Watermelon [Citrullus lanatus (Thunb.) Matsum. \& Nakai] is a widespread Cucurbitaceae, native to the drier areas of south-central Africa, near the Kalahari Desert (Namibia and Botswana). Watermelon has a great socioeconomic importance worldwide, being cultivated in many countries as China, Iran, Turkey and Brazil [1], in which together hold over $76 \%$ of world production [2]. In 
addition, watermelon has a narrow genetic base and the use of new hybrids has increased in commercial production [3].

In Brazil, the watermelon is the fourth most important crop, with a cultivated area of 105 thousand hectares and a yield of 2.3 million tons of fruit in 2017 [2]. The Brazilian Northeast region stands out as the main watermelon producer region [4], in which the harvested area in 2017 was 36.864 thousand hectares [5]. There are many traditionally watermelon cultivars available in the Brazilian commercial market, however, besides the genetic aspects, the selection of the cultivars is based on the logistics network by the selection of the transport-resistant and better appearance products [4]. Nowadays, attributes such as small fruit size, a trait that facilitates transport and packaging, as well as the absence of seeds in the fruits are aspects commercially exploited by companies as a market novelty and constitute key attributes for crop expansion $[6,7]$.

Watermelon fruits have chemical and functional compounds, especially $\beta$-carotene, total carotenoids and lycopene, potential antioxidant sources, which inhibit or retard the free radical activity in the human body, helping to minimize the occurrence or development of cancerous and degenerative diseases [8-10]. Changes in market trends have increased in the last decade [11], especially in the horticultural crops as watermelon. Besides good quality and functional compounds, the personal demand for mini $(<3 \mathrm{Kg})$ and midi $(3-7 \mathrm{Kg})$ watermelon cultivars and especially for seedless watermelon cultivars have increased [12].

Seedless watermelons are technically known as triploid hybrids, contrary to the commercial varieties as Crimson Sweet and, the hybrids as 'Quetzali' and 'Boston', that show seeds [4]. The fruits are resultant of the hybridization process by crossing a combination of a tetraploid line as a female and, a diploid line as a male [13]. In breeding programs, specifically in the melon and watermelon breeding, the study of heterosis or "hybrid vigor" is a primary factor to be considered for the selection of the most promising seeds or seedless watermelons hybrid combinations [14] as it may present vigor or promising traits compared to non-hybrids [15].

Investigations regarding the performance of new commercial seedless hybrids cultivated in the Northeast region of Brazil are lack, especially on the postharvest quality and bioactive potential. Information on the physicochemical constituents and bioactive compounds of fruits of new hybrids is an important tool for the viability of consumption and value addition. Thus, the present investigation aimed to evaluate the prospection of the quality and the bioactive potential of four seedless watermelon hybrids ('Ashira', 'Extasy', 'Mickylee' and 'Valentino'), cultivated under conventional management in the climatic conditions of the Brazilian semiarid.

\section{MATERIAL AND METHODS}

Fruits of watermelon hybrids were collected from the commercial farms located at the JaguaribeAçu agricultural Valley, mesoregion of the Potiguar West, Rio Grande do Norte, Brazil (5¹1'17"S, $37^{\circ} 20^{\prime} 39^{\prime \prime} \mathrm{W}$, tropical climate with a dry season, classified by Köppen-Geiger: As) and Jaguaribe Valley, located in the mesoregion of Ceará state, Brazil ( $5^{\circ} 4^{\prime} 40^{\prime \prime S}, 37^{\circ} 59^{\prime} 7^{\prime \prime} \mathrm{W}$, tropical climate with a dry season, classified by Köppen-Geiger: As).

Plant material included the hybrids 'Ashira', 'Extasy', 'Mickylee' and 'Valentino', both seedless. The fruits were monitored and harvested at the fully ripe. The harvest was carried out in the early morning, selected based on homogeneity and absence of defects. The fruits were sent to the postharvest laboratory at Brazilian Agricultural Research Corporation (EMBRAPA), Fortaleza-CE, Brasil, where they were previously sanitized, for further postharvest evaluation.

For the physical evaluations, fifteen fruits were taken and individual measurements were carried out for each fruit among all the studied hybrids. The fruits were divided into three portions (five fruits per repetition), processed in a multiprocessor for physicochemical and bioactive compounds analysis.

Physical variables: fruit weight (g) evaluation was carried out with the aid of semi-analytical scale and values expressed in grams; longitudinal and transverse diameter $(\mathrm{cm})$ and shell thickness (cm) (thickness + white pulp) were determined with the aid of a millimeter ruler, with a reading for each half of the fruit; fruit shape index was established from the ratio between longitudinal and transverse diameter; pulp firmness, determined by using a hand-held penetrometer (MagnessTaylor model FT 011) with results expressed in Newton (N); pulp color, performed by a digital 
colorimeter (MINOLTA, Chroma Meter Model CR-200B) using a CIELAB system (L*, a* and b*) [16].

Physicochemical variables: soluble solids (SS), was determined by AOAC (2005) [17] using a digital refractometer (ATAGO ${ }^{\circledR} \mathrm{N} 1$, Kirkland-USA), with the results expressed in ${ }^{\circ}$ Brix; titratable acidity (TA) of the pulp was carried with the aid of a pH meter, using $0.1 \mathrm{~N} \mathrm{NaOH}$ until reaching $\mathrm{pH} \pm 8,1$ [17]. One gram of juice was diluted to $50 \mathrm{~mL}$ of water under constant agitation. The results were expressed as a percentage of malic acid. The $\mathrm{pH}$ of the pulp was measured in the pure juice of the pulp using a digital $\mathrm{pH}$ meter (Mettler DL 12) [17]. The SS/TA ratio was obtained by the quotient between the two characteristics [17]; total soluble sugars (\%), determined by the Antrona method, according to Yem and Willis (1954) [18], with modifications; Reducing sugars (\%), determined by the DNS method, according to Miller (1959) [19], with modifications.

With modifications, Bioactive compounds and antioxidant activity Vitamin $\mathrm{C}$ was determined according to Arya et al. (2000) [20]; Total anthocyanins and yellow flavonoids (100g $\left.{ }^{-1}\right)$ according to Francis (1982) [21]; Total carotenoids $\left(100 \mathrm{~g}^{-1}\right)$ determined by the Higby (1962) [22]; Total extractable polyphenols $\left(100 \mathrm{~g}^{-1}\right)$ according to Larrauri et al. (1997) [23] and Lycopene $\left(100 \mathrm{~g}^{-1}\right)$ according to Rodriguez-Amaya (2001) [24].

The experiment was carried out in a completely randomized design with three replications. Analysis of variance (F-test with significance level $p<0,05$ ) was performed by using the statistical software JMP (SW-SAS) version 13.0.

\section{RESULTS E DISCUSSION}

Significant differences were found on the physical characterization of the fruits (Table 1).

Table 1. Physical characteristics of the fruits of the different watermelon hybrids cultivated at the states of Ceará and Rio Grande do Norte, Brazil.

\begin{tabular}{|c|c|c|c|c|c|c|}
\hline \multirow[b]{2}{*}{ Hybrids } & \multicolumn{6}{|c|}{ Physical characteristics } \\
\hline & FW (g) & LD (cm) & TD (cm) & FSI & ST (cm) & $\mathbf{F}(\mathbf{N})$ \\
\hline 'Ashira' & $2590,29^{b}$ & $17,86^{\mathrm{b}}$ & $17,16^{\mathrm{b}}$ & $1,04^{\mathrm{ab}}$ & $1,18^{\mathrm{ab}}$ & $16,27^{\mathrm{ab}}$ \\
\hline 'Extasy' & $2335,26^{\mathrm{b}}$ & $16,91^{\mathrm{c}}$ & $16,42^{\mathrm{b}}$ & $1,03^{\mathrm{b}}$ & $1,27^{\mathrm{ab}}$ & $17,43^{\mathrm{a}}$ \\
\hline 'Mickylee' & $2582,91^{\mathrm{b}}$ & $17,82^{\mathrm{b}}$ & $17,17^{\mathrm{b}}$ & $1,03^{\mathrm{b}}$ & $0,99^{\mathrm{b}}$ & $13,46^{\mathrm{c}}$ \\
\hline 'Valentino' & $5398,80^{\mathrm{a}}$ & $23,06^{\mathrm{a}}$ & $21,53^{\mathrm{a}}$ & $1,07^{\mathrm{a}}$ & $1,55^{\mathrm{a}}$ & $14,43^{\mathrm{bc}}$ \\
\hline MV & 3226,82 & 18,91 & 18,07 & 1,04 & 1,25 & 15,40 \\
\hline $\mathrm{VC}(\%)$ & 10,02 & 4,32 & 3,99 & 3,78 & 24,89 & 13,30 \\
\hline
\end{tabular}

Overall, 'Valentino' showed average fruit weight 53\% higher than the other hybrids. However, all the hybrids evaluated in this study showed fruits considered small, i.e., "icebox" type, with mean values lower than $5.5 \mathrm{~kg}$, according to the Maynard (2001) classification [9]. In the United States, in addition to the icebox type, commercial watermelon fruits are, in general, classified into four categories: small (5.5-8.0 kg), medium (8.1-11.0 kg), large (11,1-14.5 kg) and extra-large (greater than $14.5 \mathrm{~kg}$ ) [9]. Martins et al. (2013) [25] reported average fruit weight around $3.7 \mathrm{~kg}$ under uses of biostimulants in the 'Quetzali' and 'Style' hybrids whereas Tavares et al. (2019) [3] investigated the effect of heterosis in 15 watermelon hybrids and reported average fruit weight ranging from 6 to $10 \mathrm{~kg}$, both results outstanding 2-4fold than all of our studied hybrids. In the Brazilian market, it still prevails the appreciation for fruits with weight above $6 \mathrm{~kg}$, Crimson Sweet standard [25]. However, it is noteworthy that due to the reduction in family size, there is a growing demand for smaller fruits (under $6 \mathrm{~kg}$ ), which facilitate consumption and avoid waste [4, 7], as long as stimulate and facilitates the breeding and selection of hybrids as those evaluated in our research.

The hybrid 'Valentino' also showed the highest average values for longitudinal and transverse diameters as well as fruit shape index, due to the larger size of its fruits in accordance with Yau et al. (2010) [26], evaluating changes in the physical properties of seedless watermelon during storage. 
In the fruit shape index, it was observed that the hybrids presented FSI above 1, which suggests that all hybrids are spherical and, thus, they have a higher portion of edible pulp which lead them to advantages in boxed accommodation, i.e., facilities during the transportation, especially in this case, where fruits are considered small (average fruit weight less than $6 \mathrm{~kg}$ ) $[4,26]$.

The 'Valentino' showed the highest average shell thickness (thickness+white pulp) $(1.55 \mathrm{~cm})$. Therefore, this genetic trait may decrease the response to external factors, in which higher postharvest resistance compared to the hybrid 'Mickylee', which exhibited the smallest ST (0.99 $\mathrm{cm}$ ), a genetic trait inherent to the hybrid itself, which implies greater handling attention on the transportation. The results presented hence are in accordance with the findings of Fernandes et al. (2014) [27] in watermelon submitted to the frequencies of nitrogen irrigation and fertigation. The shell thickness is basically related to its strength due to the watermelon production system is predominantly made in bulk, requiring a shell thickness that supports the handling of the fruits [4].

The hybrid 'Extasy' showed the highest average pulp firmness (17.43 N). Thus, this hybrid may have a greater resistance to mechanical injuries sustained due to transport, besides a long shelf life compared to the hybrid 'Mickylee', which showed the lowest average pulp firmness for the same trait $(13.46 \mathrm{~N})$ among all the studied hybrids. Recent findings have reported that the variation in fruit firmness correlates with variation in cell composition, density and size, addition to polyuronide fractions, and possibly with the regulation of osmotic cell pressure by osmolytes such as citrulline [11, 28]. Araújo et al. (2016) [29], reported for 'Style' hybrids, average pulp firmness around 6.48 $\mathrm{N}$ and highlighted loses in the resistant.

Significant differences were found in the colorimetric analysis of the fruits (Table 2).

Table 2. Colorimetric analysis (CIELAB) $\left(L^{*}, a^{*}, b^{*}\right)$ and ${ }^{\circ}$ Hue of the pulp of different watermelon hybrids cultivated at the states of Ceará and Rio Grande do Norte, Brazil.

\begin{tabular}{ccccc}
\hline & \multicolumn{4}{c}{ Colorimetric analysis } \\
\cline { 2 - 5 } Hybrids & $\mathbf{L}^{*}$ & $\mathbf{a}^{*}$ & $\mathbf{b}^{*}$ & ${ }^{\circ}$ Hue \\
\hline 'Ashira' & $36,07^{\mathrm{ab}}$ & $20,36^{\mathrm{ab}}$ & $10,15^{\mathrm{b}}$ & $26,84^{\mathrm{b}}$ \\
'Extasy' & $33,05^{\mathrm{b}}$ & $22,44^{\mathrm{a}}$ & $16,73^{\mathrm{a}}$ & $36,86^{\mathrm{a}}$ \\
'Mickylee' & $37,94^{\mathrm{a}}$ & $17,21^{\mathrm{b}}$ & $9,00^{\mathrm{b}}$ & $27,59^{\mathrm{b}}$ \\
'Valentino' & $39,26^{\mathrm{a}}$ & $21,16^{\mathrm{a}}$ & $10,21^{\mathrm{b}}$ & $25,28^{\mathrm{b}}$ \\
\hline MV & 36,58 & 20,29 & 11,52 & 29,14 \\
VC $(\%)$ & 9,44 & 17,30 & 18,08 & 14,02 \\
\hline
\end{tabular}

MV: mean values; VC: variation coefficient; $L^{*}$ : luminosity; $a^{*}$ : green-red coordinate; $b^{*}:$ blueyellow coordinate; ${ }^{\circ} \mathrm{Hue:}$ Hue angle. Data represent mean values for different hybrids and different letters in the columns indicate significant differences, at $P<0.05$ ).

All the studied hybrids showed average values of luminosity $\left(\mathrm{L}^{*}\right)$ below 50 . The luminosity represents a well-reflected diffuser that probably is influenced by local climate conditions and cultivation in which the parameter $\mathrm{L}^{*}$ represents values from 0 (black or no light) to 100 (white) [30]. According to our results, 'Valentino' showed the maximum average value in the $\mathrm{L}^{*}$ component (39.26), among all the hybrids, indicating the presence of a brighter endocarp, in which the pulp may reflect more light than absorb, in accordance with findings of Oliveira et al. (2019) [4] for the hybrid 'Quetzali', which the maximum mean value for the $\mathrm{L}^{*}$ component was 41.10.

'Valentino' and 'Extasy' did not show significant differences between them for the coordinate $a^{*}$. This fact might be related to the high intense red color of the pulp that reveals a positive attribute for the watermelon fruit market, since $\mathrm{a}^{*}(+)$ represents red color and $\mathrm{a}^{*}(-)$ is linked to the green color [30].

In the CIELAB color space, $b^{*}(+)$ represents yellow and $b^{*}(-)$ reveals evolution to the blue [30]. Thus, according to our results, all hybrids showed yellow pulp color intensity with the emphasis being placed on the hybrid 'Extasy', even though the yellow color was masked by the high intense red color in the pulp.

Average Hue angle in all those studied hybrids, except 'Extasy', fit close to $29^{\circ}$, which can be considered as mature fruits, in accordance with the findings in 'Style' watermelon hybrid in which the average ${ }^{\circ} \mathrm{Hue}$ fit $28.17^{\circ}$ [29]. In the hybrid 'Extasy', ${ }^{\circ} \mathrm{Hue}$ fit close to $37^{\circ}$. Thus, we can suggest that this genotype has particularities regarding color physiology, which might be related to the high 
accumulation of carotenoids as well as lycopene, traits that may be considered for breeders during selection programs.

Significant differences were found on the physicochemical characterization, except for the $\mathrm{pH}$ measurement of the fruits (Table 3).

Table 3. Physicochemical characteristics of fruits of different watermelon hybrids cultivated at the states of Ceará and Rio Grande do Norte, Brazil.

\begin{tabular}{|c|c|c|c|c|c|c|}
\hline \multirow[b]{2}{*}{ Hybrids } & \multicolumn{6}{|c|}{ Physicochemical characteristics } \\
\hline & SS $\left({ }^{\circ}\right.$ Brix) & TA (\%) & SS/TA & pH & TSS (\%) & $\operatorname{RS}(\%)$ \\
\hline 'Ashira' & $10,28^{\mathrm{ab}}$ & $0,08^{\mathrm{b}}$ & $131,02^{\mathrm{a}}$ & $5,64^{\mathrm{a}}$ & $5,82^{\mathrm{bc}}$ & $4,48^{\mathrm{a}}$ \\
\hline 'Extasy' & $9,06^{\mathrm{b}}$ & $0,13^{\mathrm{a}}$ & $70,13^{\mathrm{b}}$ & $5,51^{\mathrm{a}}$ & $4,38^{\mathrm{c}}$ & $2,40^{\mathrm{b}}$ \\
\hline 'Mickylee' & $9,91^{\mathrm{b}}$ & $0,12^{\mathrm{ab}}$ & $78,90^{\mathrm{ab}}$ & $5,45^{\mathrm{a}}$ & $7,36^{\mathrm{ab}}$ & $2,67^{\mathrm{b}}$ \\
\hline 'Valentino' & $11,58^{\mathrm{a}}$ & $0,15^{\mathrm{a}}$ & $77,04^{\mathrm{ab}}$ & $5,43^{\mathrm{a}}$ & $9,20^{\mathrm{a}}$ & $2,52^{\mathrm{b}}$ \\
\hline MV & 10,21 & 0,12 & 89,27 & 5,50 & 6,69 & 3,02 \\
\hline $\mathrm{VC}(\%)$ & 5,69 & 14,04 & 25,16 & 3,19 & 12,50 & 13,85 \\
\hline
\end{tabular}

The average soluble solids were about $10^{\circ}$ Brix over all those studied hybrids, ranging by 9 to 11.6 'Brix, for 'Extasy' and 'Valentino', respectively. These results are in line with related studies for commercial watermelon hybrids [26, 29], which highlight that those hybrids are within the standards found in the market. The soluble solids content is a measurement of the concentration of reducing and non-reducing sugars, so that, the relative concentration of these sugars is influenced by cultivation and stage of maturity [9].

The soluble solids are a valuable measurement due to the higher total soluble solids content being associated with the greater commercial performance of the selected hybrid [3]. It is also noteworthy that soluble solids are very influenced by environmental factors, among which stand out the genotype, planting location and crop management [31]. Overall, the evaluated hybrids presented results consistent with watermelon market requirements, which is 11 to $13{ }^{\circ} \mathrm{Brix}$, an acceptable range for the most commercially prominent hybrids [9].

The SS content is routinely measured by growers to estimate fruit quality, associated with multi other traits [9]. Lately, it has been found that the absorption and accumulation of sugar in watermelon fruit pulp is associated with the expression of a sugar transport gene in the tonoplast (ClTST2), in which the increase in the expression was considered an important mechanism of watermelon domestication [32].

Overall, the average titratable acidity was about 0,12 those studied hybrids, ranging by 0.08 to $0.15 \%$ of malic acid, for 'Ashira' and 'Valentino', respectively, in line with those which were reported by Yau et al. (2010) [26], who found average titratable acidity ranging from 0.09 to $0.13 \%$, values within the acceptable limits for the consumer to market the fruit [33]. Overall, the watermelon fruits show more than $75 \%$ of malic acid followed by citrate (> 20\%) and minimal concentrations of other organic acids [33]. Thus, all the studied hybrids showed low acidity, especially 'Ashira' when compared to the other hybrids, a particular genetic trait of each genotype and may also be a result of the influence of cultivation conditions.

Whereas changes in the soluble solids and in titratable acidity, variation in the mean values of the SS/TA ratio was obtained. The hybrid 'Ashira' had an increase over 73\% in the SS/AT ratio compared to the other hybrids which represents a high proportion of sugars present in the fruit of 'Ashira' and low amount of organic acids present, being the hybrid considered more palatable compared to the others. Campagnol et al. (2012) [34], when evaluating the postharvest quality of the hybrid Smile, showed SS/TA presents ratio values close to the hybrids evaluated in this study (77.25 to 81.26). The SS/TA ratio provides indicative of the taste of the fruit, as they report the amount of sugars and acids present providing a good idea of the balance between these two components.

No statistically significant differences were found for the $\mathrm{pH}$. However, the results for all hybrids are in line with the $\mathrm{pH}$ for watermelons harvested at commercial maturity which ranging from 5.5- 
$5.8[4,26,35]$. Genetic and environmental factors considerably influence the chemical composition of the fruits not only by the variety but also due to the degree of maturity before harvest and on the postharvest and storage conditions [4].

Significant differences were found for the total soluble sugar ranging from 4.38 to $9.20 \%$ for 'Extasy' and 'Valentino' hybrids, respectively. 'Valentino' could show the best sweet taste among the hybrids, since soluble sugars are the low molecular weight carbohydrates, components of soluble solids, responsible for the sweet taste of fruits [4]. Our results are in line with Araújo et al. (2016) [29] which observed average levels of $8.23 \%$ of total soluble sugars in watermelon fruits.

The average reducing sugars was about 3,02\% over all those studied hybrids, ranging from 2.40 to $4.48 \%$ 'Ashira' and 'Extasy', respectively, in line with Araújo et al. (2016) [29] (5.52\%). It is noteworthy that the main sugars present in cucurbits are, in general, glucose, fructose, and sucrose. Reducing sugars contribute with almost the majority of the total sugar content in the early stage of fruit development; However, sucrose can reach up to $50 \%$ of total sugars in the final maturation phase, with an approximate proportion of $25 \%$ for glucose and $25 \%$ for fructose [36].

Regarding the bioactive compounds, significant differences were found only for the contents of lycopene and total polyphenols content (Table 4).

Table 4. Bioactive compounds of fruits of different watermelon hybrids cultivated at the states of Ceará and Rio Grande do Norte, Brazil.

\begin{tabular}{ccccccc}
\hline & \multicolumn{6}{c}{ Bioactive compounds } \\
\cline { 2 - 7 } Hybrids & $\mathbf{V C}$ & $\mathbf{C T}$ & FA & ANT & LYC & PET \\
\hline 'Ashira' & $9,35^{\mathrm{a}}$ & $2,46^{\mathrm{a}}$ & $4,94^{\mathrm{a}}$ & $0,61^{\mathrm{a}}$ & $1,06^{\mathrm{a}}$ & $238,10^{\mathrm{a}}$ \\
'Extasy' & $8,67^{\mathrm{a}}$ & $2,57^{\mathrm{a}}$ & $5,52^{\mathrm{a}}$ & $0,54^{\mathrm{a}}$ & $1,09^{\mathrm{a}}$ & $96,94^{\mathrm{b}}$ \\
'Mickylee' & $7,97^{\mathrm{a}}$ & $1,72^{\mathrm{a}}$ & $5,97^{\mathrm{a}}$ & $0,64^{\mathrm{a}}$ & $0,55^{\mathrm{b}}$ & $219,06^{\mathrm{a}}$ \\
'Valentino' & $8,12^{\mathrm{a}}$ & $2,35^{\mathrm{a}}$ & $4,22^{\mathrm{a}}$ & $0,51^{\mathrm{a}}$ & $0,85^{\mathrm{ab}}$ & $229,95^{\mathrm{a}}$ \\
\hline MG & 8,53 & 2,27 & 5,16 & 0,57 & 0,89 & 196,01 \\
CV $(\%)$ & 6,99 & 14,59 & 23,79 & 42,34 & 14,08 & 5,91
\end{tabular}

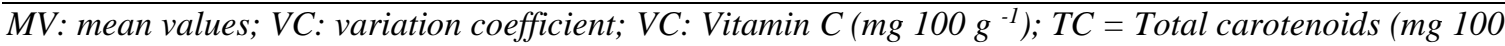
$\left.\mathrm{g}^{-1}\right) ; F A=$ yellow flavonoids $\left(\mathrm{mg}^{100 \mathrm{~g}^{-1}}\right) ; \mathrm{TA}=$ total anthocyanins $\left(\mathrm{mg}^{100 \mathrm{~g}^{-1}}\right) ; \mathrm{LYC}=\left(\mathrm{mg}_{100 \mathrm{~g}^{-1}}\right)$; PET $=$ Total extractable polyphenols $\left(\mathrm{mg}^{1} 100 \mathrm{~g}^{-1}\right)$. Data represent mean values for different hybrids and different letters in the columns indicate significant differences, at $P<0.05$ ).

Watermelon provides a wide variety of antioxidants such as carotenoids (lycopene and $\beta$ carotene), phenols, vitamins (A, B, C and E) and specific amino acids (citrulline and arginine) believed to play a protective role in reducing of the risk of certain cancers, cardiovascular disease and age-related degenerative pathologies $[9,10]$.

The bioactive results related to the content of vitamin $\mathrm{C}$, total carotenoids as well as anthocyanin and flavonoids fall in line with findings in other genotypes [4, 10, 29, 37], even though no significant differences were found for these characteristics. Vinson et al. (2001) [38] reported that watermelon is classified as one of the main fruits of consumption in the world market, highlighting, as the main marketing centers, America and Europe, which provide about 80 and $50 \%$ of the intake of such compounds daily. Thus, our seedless watermelon hybrids produced at northeastern semiarid have high-quality hence being indicated as market novelty due to the high phytochemical content.

Overall, 'Extasy' showed average lycopene content 49\% higher than 'Mickylee' which presented

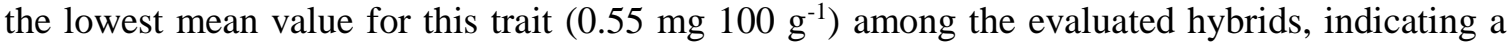
genetic variation in the pigment synthesis in each material. Different environmental conditions, especially light and temperature may amplify this variability, contributing to differences in values observed under different geographical areas [39]. The variation in the lycopene content might be also due to a differentiated activation of the molecular mechanisms involved in the carotenogenesis regulation during ripening stages, followed by feedback inhibition of the pathway by end-products towards the end of fruit ripening [10].

In the watermelon fruits, the lycopene content may vary according to the ripening stage of the fruit, in which the highest rate of synthesis and accumulation in the chromoplasts can be detected in the transition phase between the "white-pink" and "pink" stages" [10]. In line with the findings reported by Perkins-Veazie et al. (2001) [40] in 11 seedless watermelon hybrids as well as for those 
reported by Oliveira et al. (2019) [4] for the hybrid 'Boston' and 'Quetzali', but lower to the results found by Leão et al. (2006) [41] who evaluated 8 watermelon cultivars for lycopene content under commercial orchard of 'Charleston Gray' and 'Smile', respectively.

Significant differences were found for the total polyphenols in which 'Ashira' standing out compared to the 'Extasy' which showed the lowest content. Our findings are in line with those reported by Tlili et al. (2011) [10] as well as Oliveira et al. (2019) [4]. Haminiuk et al. (2012) [42] reports that phenolic compounds are metabolites widely found in fruits and that the interest in such substances is mainly due to antioxidant activity in preventing diseases. In general, it is observed that although polyphenol levels in watermelons are considered lower than other fruits, the high consumption of this fruit, can contribute considerably to the daily intake of such compounds.

\section{CONCLUSION}

The fruits of the seedless watermelon hybrids cultivated under conventional management at the Brazilian semiarid area are promising alternatives to the local and export watermelon market, in view of the high quality and bioactive potential linked to the good adaptability and stability under the growth conditions.

\section{REFERENCES}

1. Sultana B, Ashraf R. Watermelon (Citrullus lanatus) oil. In: Fruit Oils: Chemistry and Functionality. Cham: Springer International Publishing; 2019 Sep;29:741-56.

2. The Food and Agriculture Organization (FAO). Crops. Available from: Access on: Sep. 29, 2019.

3. Tavares AT, Lopes DAP da S, Alves FQG, Santos GR, Nascimento IR. Heterose em híbridos de melancia. J Neotrop Agric. 2019 May;6(2):26-33, doi:10.32404/rean.v6i2.2658

4. Oliveira MMT, Alves RE, Silva LR da, Aragão FAS. Qualidade de frutos de híbridos de melancia com sementes. Rev Fac Agron. 2019 Jun;118(1):80-6, doi:10.24215/16699513e008

5. Instituto Brasileiro de Geografia e Estatística (IBGE). Sidra. Available from: Access on: Sep. 29, 2019.

6. Alam M, Hoque M, Morshed S, Shahriar S, Begum A. A study on watermelon (Citrullus Lanatus) juice preserved with chemical preservatives at refrigeration temperature. J Environ Sci Nat Resour. 2013 Apr;5(2):23-8. doi:10.3329/jesnr.v5i2.14597

7. Gusmini G, Wehner TC. Heritability and genetic variance estimates for fruit weight in watermelon. HortScience. 2007 Oct;42(6):1332-6. doi:10.21273/HORTSCI.42.6.1332

8. Agarwal S, Rao AV. Tomato lycopene and its role in human health and chronic diseases. CMAJ . 2000 Sep;163(6):739-44.

9. Maynard DN. Watermelons: characteristics, production, and marketing. ASHS Press; 2001. Breeding and improvement; p-39-65.

10. Tlili I, Hdider C, Lenucci MS, Ilahy R, Jebari H, Dalessandro G. Bioactive compounds and antioxidant activities during fruit ripening of watermelon cultivars. J Food Compos Anal. 2011 May;24(7): 923-928, doi: 10.1016/j.jfca.2011.03.016

11. Kyriacou MC, Rouphael Y, Colla G, Zrenner R, Schwarz D. Vegetable grafting: the implications of a growing agronomic imperative for vegetable fruit quality and nutritive value. Front Plant Sci. 2017 May;8: 1-23, doi:10.3389/fpls.2017.00741

12. Freeman JH, Olson SM. Characteristics of watermelon pollenizer cultivars for use in triploid production. Int J Veg Sci. 2007 Dec;13(2):73-80, doi: 10.1300/J512v13n02_07

13. Kihara H. Triploid watermelons. In: Proceedings of the American Society for Horticultural Science. 1951, p. 217-30.

14. Souza F de F, Dias R de CS, de Queiróz MA. Capacidade de combinação de linhagens avançadas e cultivares comerciais de melancia. Hortic Bras. 2013 Oct;31(4): 595-601, doi: 10.1590/S010205362013000400014

15. Barros HB, Sediyama T, Teixeira R de C, Fidelis RR, Cruz CD, Reis MS. Adaptabilidade e estabilidade de genotipos de soja avaliados no estado do Mato Grosso. Rev Ceres. 2010 Jun;57(3):359-66, doi: 10.1590/S0034-737X2010000300011

16. McGuire RG. Reporting of Objective Color Measurements. HortScience. 1992 Dec;27(12):1254-5, doi: 10.21273/HORTSCI.27.12.1254

17. Association of Official Analysis Chemists International (AOAC). Official Methods of Analysis of AOAC International. Association of Official Analysis Chemists International. 2005.

18. Yem W. The estimation of carbohydrates in plant extracts by anthrone. Biochem J . 1954 Jul;57(3):50814. 
19. Miller GL. Use of dinitrosalicylic acid reagent for determination of reducing sugar. Anal Chem. 1959 Mar;31(3):426-8, doi:10.1021/ac60147a030

20. Arya S, Mahajan M, Jain P. Non-spectrophotometric methods for the determination of vitamin C. Anal Chim Acta. 2000 Jul;417(1):1-14, doi: 10.1016/S0003-2670(00)00909-0

21. Francis JF. Analysis of Anthocyanins. In: Anthocyanins as Food Colors. Elsevier Science; 1982. p. 280.

22. Higby WK. A Simplified Method for Determination of Some Aspects of the Carotenoid Distribution in Natural and Carotene-Fortified Orange Juice. J Food Sci. 1962 Jan;27(1):42-9, doi: 10.1111/j.13652621.1962.tb00055.x

23. Larrauri JA, Rupérez P, Saura-Calixto F. Effect of drying temperature on the stability of polyphenols and antioxidant activity of red grape pomace peels. J Agric Food Chem. 1997 Apr;45(4):1390-3, doi: $10.1021 / \mathrm{jf} 960282 \mathrm{f}$

24. Rodriguez-Amaya DB. A guide to carotenoid analysis in foods. Life Sciences. 2001.

25. Martins JCP, Aroucha EMM, De Medeiros JF, Do Nascimento IB, Sales De Paula VF. Características pós-colheita dos frutos de cultivares de melancia, submetidas à aplicação de bioestimulante. Rev Caatinga. 2013;26(2)18-24.

26. Yau EW, Rosnah S, Noraziah M, Chin NL, Osman H. Physico-chemical compositions of the red seedless watermelons (Citrullus Lanatus). Int Food Res J. 2010;7(2) 327-334.

27. Fernandes CNV, Azevedo BM de, Nascimento Neto JR, Viana TV de A, Sousa GG de. Irrigation and fertigation frequencies with nitrogen in the watermelon culture. Bragantia. 2014 Jun;73(2):106-12, doi: 10.1590/brag.2014.027

28. Soteriou GA, Siomos AS, Gerasopoulos D, Rouphael Y, Georgiadou S, Kyriacou MC. Biochemical and histological contributions to textural changes in watermelon fruit modulated by grafting. Food Chem. 2017;237(1):133-140, doi: 10.1016/j.foodchem.2017.05.083

29. Araújo NO de, Aroucha EMM, Chaves SWP, Medeiros JF de, Paiva CA de, Sílva AC da, et al. Quality of seedless watermelon cultivated under different doses and phosphorus application forms. African $\mathbf{J}$ Agric Res. 2016 Dec 22;11(51):5136-44, doi: 10.5897/AJAR2016.11638

30. Minolta K. Precise Color Communication: color control from feeling to instrumentation. National Technical Conference - AATCC (American Association of Textile Chemists an. 1998.

31. Deswal IS, Patil VK. Effects of N, P and K on the fruit of water melon. J Mah Agric Univers. 1984;9(1):308-9.

32. Ren Y, Guo S, Zhang J, He H, Sun H, Tian S, et al. A tonoplast sugar transporter underlies a sugar accumulation QTL in watermelon. Plant Physiol. 2018;171(1):836-850, doi: 10.1104/pp.17.01290

33. Fredes A, Roselló S, Beltrán J, Cebolla-Cornejo J, Pérez-de-Castro A, Gisbert C, et al. Fruit quality assessment of watermelons grafted onto citron melon rootstock. J Sci Food Agric. 2017;97(5): 16461655, doi: $10.1002 /$ jsfa. 7915

34. Campagnol R, Mello S da C, Barbosa JC. Vertical growth of mini watermelon according to the training height and plant density. Hortic Bras. 2012;30(4):726-732, doi: 10.1590/S0102-05362012000400027

35. Kyriacou MC, Leskovar DI, Colla G, Rouphael Y. Watermelon and melon fruit quality: The genotypic and agro-environmental factors implicated. Scientia Horticulturae. 2018;234(1):393-408, doi: 10.1016/j.scienta.2018.01.032

36. Long RL, Walsh KB, Rogers G, Midmore DJ. Source-sink manipulation to increase melon (Cucumis melo L.) fruit biomass and soluble sugar content. Aust J Agric Res. 2004;55(12):1241, doi: 10.1071/AR04157

37. Lee SK, Kader AA. Preharvest and postharvest factors influencing vitamin C content of horticultural crops. Postharvest Biology and Technology. 2000;20(3):207-220, doi: 10.1016/S0925-5214(00)00133-2

38. Vinson JA, Su X, Zubik L, and Bose P. Phenol Antioxidant Quantity and Quality in Foods: Fruits. J. Agric. Food Chem., vol. 49, no. 11, pp. 5315-5321, Nov. 2001.

39. Dumas Y, Dadomo M, Di Lucca G, Grolier P. Effects of environmental factors and agricultural techniques on antioxidant content of tomatoes. Journal of the Science of Food and Agriculture. 2003;83(5):369-382, doi: $10.1002 /$ jsfa. 1370

40. Perkins-Veazie P, Collins JK, Pair SD, Roberts W. Lycopene content differs among red-fleshed watermelon cultivars. J Sci Food Agric. 2001;81(10):983-987, doi: 10.1002/jsfa.880

41. Leão DSS, Peixoto JR, Vieira JV. Teor de licopeno e de sólidos solúveis totais em oito cultivares de melancia. Biosci J. 2006;22:7-15.

42. Haminiuk CWI, Maciel GM, Plata-Oviedo MSV, Peralta RM. Phenolic compounds in fruits - an overview. Int J Food Sci Technol. 2012;47(10): 2023-2044, doi: 10.1111/j.1365-2621.2012.03067.x 